\title{
Role of Additives in Mortars: Historic Precedents
}

\author{
Anjali Acharya*, Shubhjeet Archroy **Vasudha A Gokhale*** \\ Prof. of Chemistry*, Research Scholar**, Prof of Archetecture*** \\ Institute for Excellence in Higher Education Bhopal, BNC Collage of Architecture Pune, India.
}

\begin{abstract}
The use of lime in building construction began at least 10,000 years ago, where there are numerous evidence of its earlier uses. This research is an attempt to provide a review of the history of lime as a building material in based on available literature resources. The origin significance and sustainability of lime mortars and their use in architectural conservation is discussed. Large scale use of additives in historic buildings in India and abroad is highlighted in order to put forth their physio-chemical and aesthetical properties. Use of sustainable additives in mortar is stressed. The analysis presented is supposed to help architectural conservation experts in their efforts to safeguard the intrinsic qualities Indian cultural heritage for posterity.
\end{abstract}

Keywords: Pozzolana, volcanic, bael, gypsum, fat.

\section{INTRODUCTION}

Mortar is a important material which present in structures dating back thousands of years, the significance of lies the encoded story of an ebb and flow of knowledge. The use of mortars began with mud and clay-based mortars as low-cost "to hand" natural materials used by the early civilisations. In Egypt this progressed to mortars made with gypsum, the natural material being heated on small fires. The use of the resulting mortar (really a gypsum plaster) was alright in this relatively dry climate, but gypsum is somewhat soluble, so use elsewhere in wetter conditions was problematical. The Romans were certainly conversant with 'lime mortar' combining

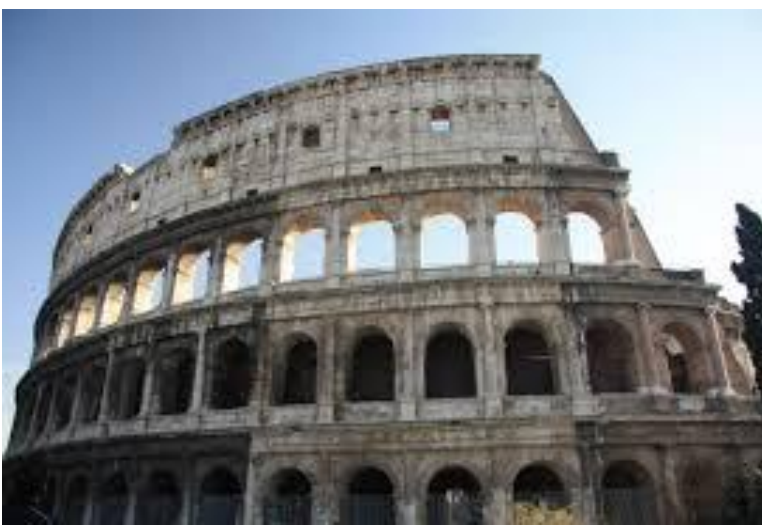

Fig.1 Roman Amphitheatre

It was also found that ground ceramic tiles and pottery would impart similar setting characteristics and many surviving Roman mortars have a reddish-pink colouration as a result. So the Greeks, Egyptians, Romans, and others in antiquity began the process of accruing empirical knowledge of lime mortars and similar products as principal constituents in measured amounts and employing the end product in buildings throughout their Empire. Romans were great innovators; constantly looking to improve, they experimented by modifying lime mortar mixes with controlled additions of naturally occurring deposits. They found in particular that volcanic ashes present in the vicinity of the town of Pozzuoli near Naples, when incorporated in a lime mortar mix, produced a material that actually set hard under water. This was revolutionary and allowed the construction of much larger buildings and other commercial-scale masonry works including bridges, harbours, aqueducts and water cisterns (Fig.1,2.).

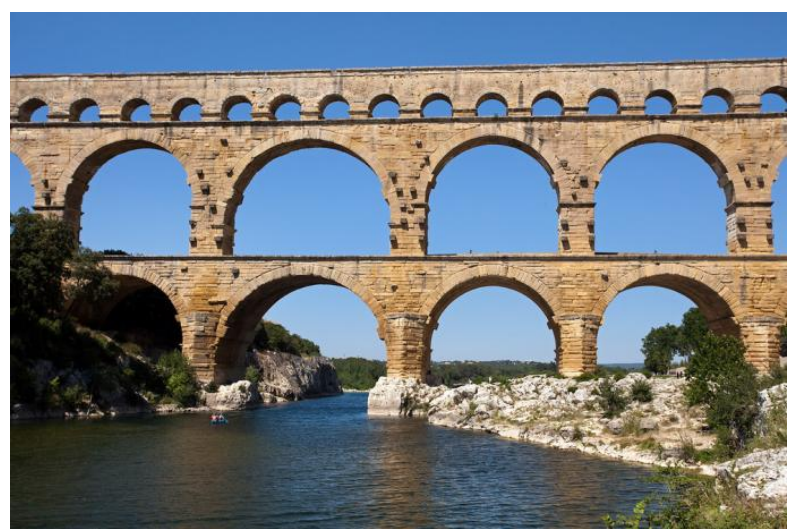

Fig.2 Roman Aqueduct

building materials. Continuity was maintained; knowledge flowing down through generations. The stream was however, to dry up in Britain with the Roman departure, after which the mortar became lost.

Practically all of the major buildings completed in the Dark Ages and medieval times 
were constructed with natural 'air lime' mortars. The ancient world had by experiment, intuition and "trial and error experience", developed a building technology ultimately based on modified lime mortar. They did not have the detailed science to explain their experience, but they had proved that certain mixes worked best for particular situations. The mortars used to bind the concrete composites used for construction of buildings of Imperial Rome have great scientific interest because of their unmatched resilience and durability as well as for the environmental advantages they offer. Roman was a mixture of about 85-percent (by volume) volcanic ash, fresh water, and lime, which was calcined at much lower temperature than Portland cement. Coarse chunks of volcanic tuff and brick compose about 45-to-55-percent (by volume) of the concrete. The result was a significant reduction in carbon emissions.

In 1824 came the first patent for Portland Cement, an early form of the cement in use today and so called because its colour resembled that of best Portland stone. The impact of Portland cement was then, by no means immediate and lime mortars remained in use in parallel with the 'new cement'. By the $20^{\text {th }}$ century the popularity of Portland cement, a material which set hard and relatively quickly and could be used in most weathers by a workforce with less specific skills, was increased by the need for faster rates of construction driven, amongst other things, by World War 1 and corresponding investment in the cement industry up to and after World War 2, when the need for extensive re-building demanded mass production of construction materials. In the UK the importance of preserving building heritage and historic environment was recognised from the late 19th century onwards with the formation of various local and national bodies and societies dedicated to this end. However a revival of lime mortar application noticed in conservation of historic buildings because of identification of the unfavorable properties of Portland cement mortars such as brittleness, high strength, and a thermal expansion coefficient which can be twice as large as that of lime mortars and most types of brick and stone,

\section{PROPERTIES OF LIME MORTAR}

Mortars are binding materials comprised of a binder, such as lime, gypsum or cement, and an aggregate, such as sand or grit. They are classified two broad categories hydraulic and nonhydraulic mortars, depending on their ability to set under water. Lime mortar is generally considered to be non-hydraulic, but they may possess hydraulic properties when mixed with pozzolanic additives, or when the amount of clays or other silicates exceeds about $10 \%$ in the source material, such as limestone, marble or seashells (Arhusrt, 1990, Kuhn, 1981). The main constituent of limestone is calcite, $\mathrm{CaCO} 3$ in addition it can also contain dolomite, $\mathrm{MgCa}(\mathrm{CO} 3) 2$ and impurities in varying amounts.

Lime produced from limestone with less then $5 \%$ of magnesium carbonate is referred as high-calcium lime, while limestone with a magnesium carbonate content above $20 \%$ produces dolomitic lime (Boyanton 1984). Dolomitic lime is frequently used for construction purposes and it has good high plasticity, water retention and workability (Thomson 2000, Webb 1952). However, it has been fund that dolomitic lime is not suitable for conservation purposes because late hydration of the magnesium oxide in dolomitic lime might result in poor soundness (Ramchandran 64); besides exposure to air pollutants such as sulphur dioxide might cause the formation of highly soluble, damaging magnesium sulphates (Arnold 2084).

\section{THE ADVANTAGES OF LIME OVER CEMENT}

Architects and builders from historic period accepted that dampness and moisture from rain were bound to find a way into the walls of structures to counter this problem the walls were built thick with the soft, permeable mortars with use of lime. Because of the use of lime buildings expand, contract and flex with changes in temperature and moisture and it also allows damp to be absorbed to a limited degree and then evaporate harmlessly away.

Cement is a rigid material which cannot cope with the regular small movements of the historic building as a result building often microscopically becomes cracked and water is drawn in. Cement provides a water proof surface where evaporation cannot take place and the amount of damp increases substantially. Many times it has been found that the as cement plaster is harder than the stone or brick, deterioration caused by the development of stress in the face of the wall. Main advantages are as follows:

- Lime is produced at lower temperatures than cement as a result lime mortar requires less energy, resulting in $20 \%$ less $\mathrm{CO}_{2}$ output

- Lime plaster absorbs $\mathrm{CO}_{2}$ in the curing process. Non-hydraulic lime absorbs nearly its own weight in $\mathrm{CO}_{2}$, hydraulic lime, around $75 \%$ and lower.

- Unlike cement Lime mortar can be re-cycled. In addition to this brickwork with lime mortar can be recycled which can only be used for hardcore. 
- Historic buildings built using lime mortar move and absorb moisture. and prevents masonry from cracking.

- By using lime mortar, expansion joints can be avoided. While buildings with cement mortar which is rigid, cannot move' with the structure.

- The imperviousness of cement mortar prevents absorption of water from the structure whereas lime mortar acts as a kind of 'wick', absorbing the moisture and allowing it to evaporate.

- There is less risk of spalling as lime mortar keeps the masonry dry and absorbs moisture.

\section{Role of Additives in Lime Mortar}

The role of additives in mortars has rarely researched as most of the literature focuses on the addition of organic compounds to the mortar paste for various purposes (Sickels 1981; Arcolao 1998; Carbonara 2007). Various materials like ash and brick dust are widely used which enable lime mortars to set more rapidly. Additives are required as simple non-hydraulic lime mortars harden by drying and carbonation, which is by the conversion of calcium hydroxide (slaked lime) to calcium carbonate by reaction with atmospheric carbon dioxide. In hydraulic mortars the hardening process is supplemented by chemical reactions between calcium hydroxide and reactive silicates and aluminates in the presence of water. In natural hydraulic limes the reactive silicates and aluminates are supplied by clay minerals in the limestone.

The term 'pozzolan' derives from the volcanic ash Pozzuoli in Italy, which was used by the Romans with lime mortars. It include material such as brick dust which is added to a nonhydraulic lime mortar to give it hydraulic properties, as a result of this the mortar sets without exposure to carbon dioxide in the air because unlike cement, pozzolanic additives do not reduce the permeability of mortars but enhance it. Where a hydraulic set is required in a lime mortar and these minerals are not naturally present, or are not present in sufficient quantities, they can be added in the form of pozzolans as additives. The addition of pozzolan as an additive to lime mortar modify mortar's characteristics which combine with uncarbonated lime (calcium hydroxide) to form stable compounds, thus reducing the risk of early leaching or frost damage and increasing the durability of the mortar. The density and compressive strength of the mortar may be increased and porosity reduced as per the type of pozzolana selected as additive. It has been found that the softer pozzolanic materials like brick dust from clay bricks fired at less than $950^{\circ} \mathrm{C}$ produce more permeable and flexible mortars, whilst the hard-burned materials, such as
PFA, tend to produce a harder mortar, closer in its characteristics to cement.

\section{Other Additives}

Research identified the presence of a wide variety of other additives, such as casein, beer and oil mastics in historic buildings. Various additives were used in historic buildings which include polysaccharides also known as nopal used either as a powder or as mucilage, proteins in the form of animal glue and casein and fatty acids like olive oil. Research established that use of these additives increased mechanical properties and waterresistance, different carbonation speeds, and different textures. They are all compatible with traditional building materials, so they can be used in the restoration of architectural heritage and modern architecture where natural stone is used. It has been found that Olive oil used as additive in the lime mortar, improve mortar impermeability. Animal glue used as additive in the lime mortar, increase the mechanical resistance. Lime mortar carbonation front was significantly improve by addition of nopal. Research based on analytical procedures to identify the organic additives in lime mortars by classical chemical analysis show that using iodine-potassium iodide reagent, Benedict's reagent, reduction phenolphthalein reagent, brilliant blue and sodium periodate oxidation glycerin acetyl acetone method could effectively detect a small amount of starch, reducing sugar, blood, protein and fatty acid ester that remained in ancient buildings' lime mortars, respectively (Shi Qiang 2014).

Research on the medieval military shipyard of Amalfi, Italy revealed a saccharide material-based additive in the mortars, of plant origin. The FT-IR spectra suggested the presence of a natural gum, which has been used since ancient times to strengthen the cohesion properties of mortars and their resistance to tensile stress. According to ancient literature, crop flour and blood have been used as binders in the mortars of Chinese wooden buildings. Study on three ancient buildings the Old Summer Palace (18th and early 19th centuries), the Eastern Royal Tombs of the Qing Dynasty (middle 17th to early 20th centuries) and the Taiyuan Confucius Temple (late 19th century), indicated the presence of proteins, and then different organic additives, namely, wheaten flour, cattle blood and pig blood, were identified respectively in the three mortars by LC/MS/MS analysis (Huiyun Rao et al 2015) 


\section{ADDITIVE IN INDIAN HISTORIC BUILDINGS}

Indian traditional structures built with lime mortar, which are more than 4,000 years old like Mohenjo-Daro is still a heritage monument of Indian civilization. Qutub Shahi kings to make extensive use of lime-mortar in almost all the monuments and palaces built by them. In India, many indigenous materials such as surkhi (crushed bricks), batasha (sweet sugar drops), urad ki dal (white lentil), egg white, malai (cream), tambakoo sheera (juice of tobacco) were largely used as an additives to mortar which were introduced in Akbar's period but extensively used as an adhesive

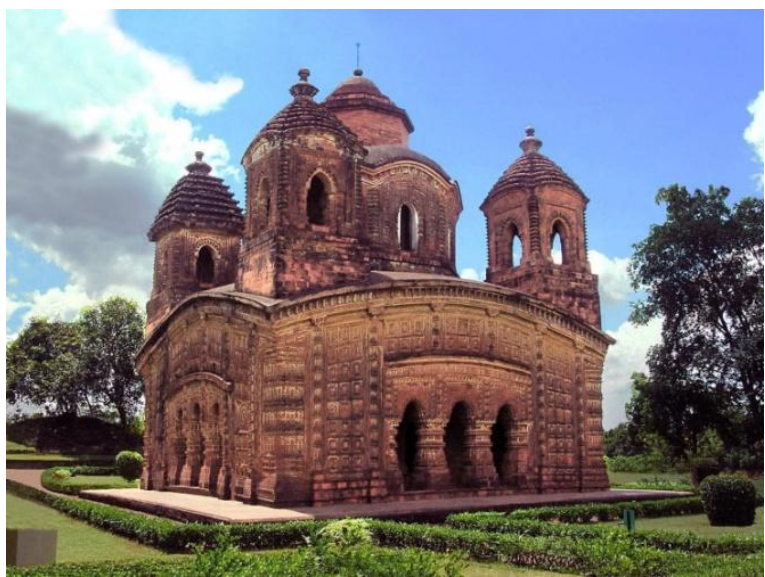

Fig 3. Shavmrai Temple, Bishnupur.

It is observed that an old Monuments in Gandikota at Kadapa dist, where bonding between the stones was achieved by mortar with combination of lime, sand and jaggery juice. Concrete made with admixtures like sugar and jiggery can be utilised in particular situations. Usage of these admixtures will decrease the segregation and bleeding. Sugar is a carbohydrate, a substance composed of carbon, oxygen and hydrogen. Jaggery is made from the product of

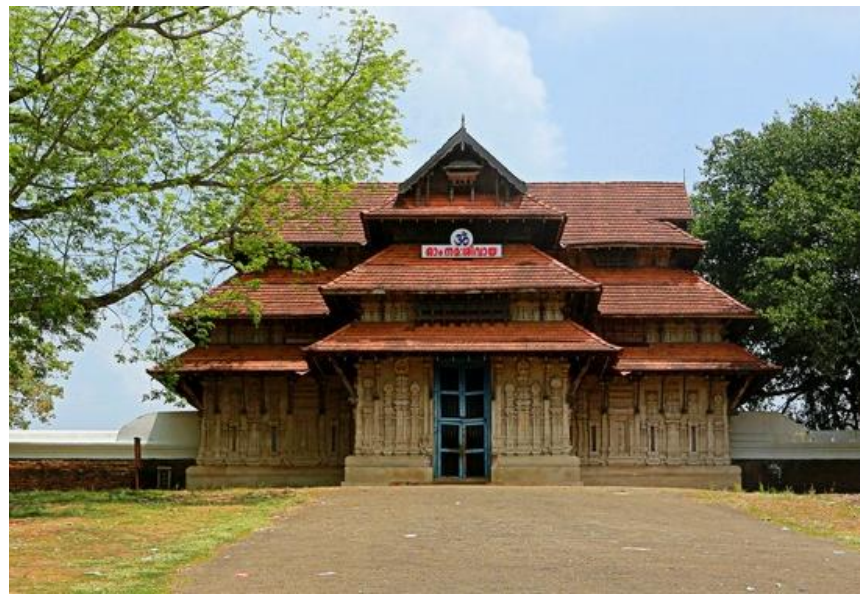

Fig.5. Vadakkunnathan temple at Thirrsur, Kerala from the period of Shah Jahan in addition to this bel giri (Aegle marmelos) were also added to the lime. Jute is used in some cases to prevent cracks. Jaggery was another was mixed with lime, sand and clay and used as cement for joining bricks. Jaggery, which is predominantly sucrose, upon reacting with calcium carbonate in lime and silica in clay, forms strong bonds and became very hard on drying. Some examples of such buildings can still be seen in West Bengal and in other parts of India if they are still standing (fig 3). At Hiran Minar Pakistan the technology of Lime Mortar has proven that it is the best water-proof material beating even (Fig.4)

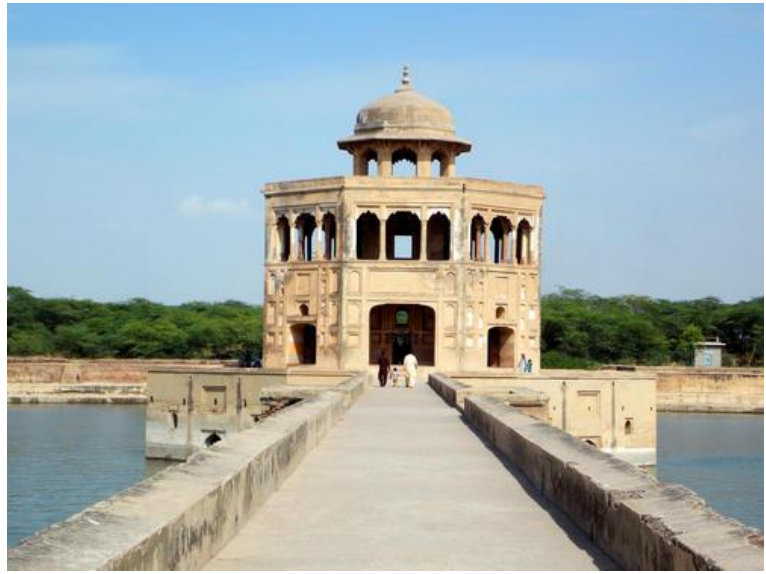

Fig.4 Hiran Minar, Sheikhupura Pakistan

sugar cane. So, both are useful to add as an admixtures in the concrete composition. Cement was replaced by Sugarcane Bagasse Ash (SCBA) in the production of mortar and concrete. Resaerch indicated use of powdered shells, nine different herbs and jiggery in retrofitting of Vadakkunnathan temple at Thirrsur, Kerala (Fig.5) and at Fort at Vettimurichakotta, Pazhavangadi, East Fort, West Fort, Puthen Street, Sreevaraham and Virakupurakkotta, Keral ( Fig.6 )

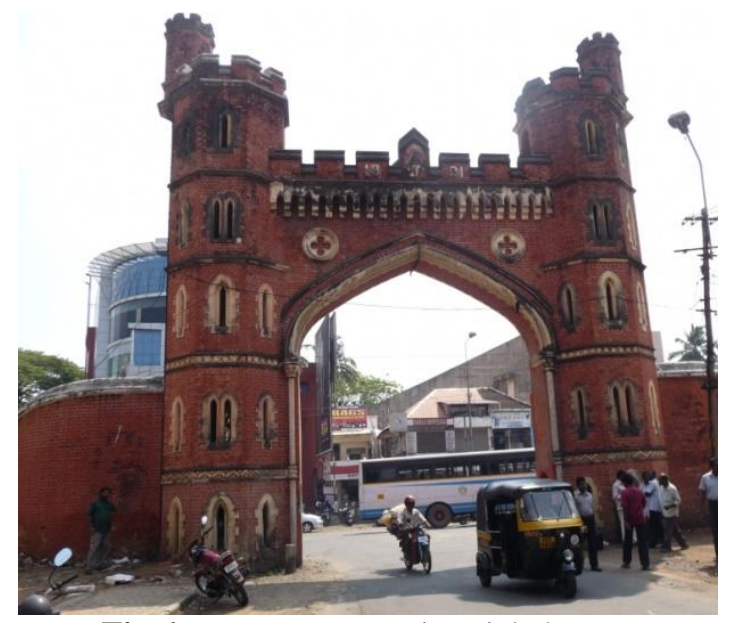

Fig.6. Fort gate at Vettimurichakotta, Pazhavangadi 
India using different composition of the plaster mixture which was discovered from a palm leaf manuscript found in the Padmanabhapuram Palace. the mortar used in most medieval buildings in Delhi was an organic mortar which, besides common building material like stone or brick dust and lime, also contained ingredients such as cow dung, fenugreek, lentils, yoghurt, and the pulp of the wood-apple or bael. Organic mortar has the advantage of letting moisture 'flow' through the building, which prevents dampness from settling in, especially in places of high rainfall, such as Delhi during the monsoon (Fig 7.) The best of Ahom architecture. The octagonal, two-storey structure stands on exotic material-jaggery, black gram, elephant grass, limestone, snail ooze, filtered lime powder, long fish bones, mustard oil, incense, and of course bricks and big stones (fig.8).

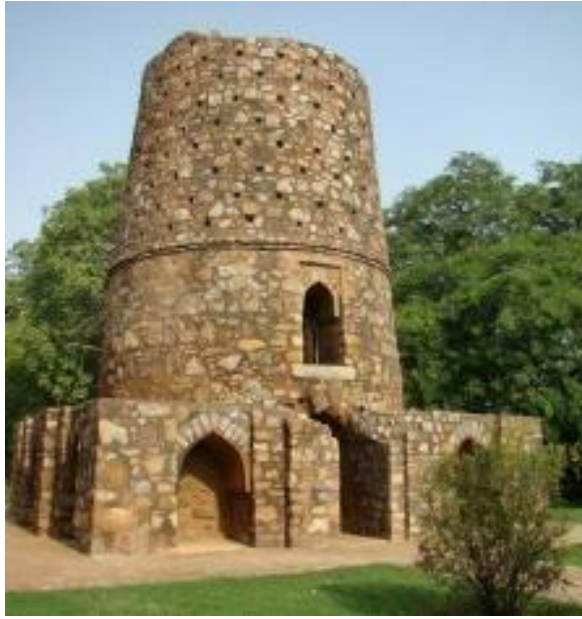

Fig.7. Chor Minar Delhi.

In Humayun'a tomb the cement plaster applied during earlier restoration attempts was replaced with traditional lime plaster. The final layer of lime plaster that gives the gate its white appearance was made by mixing marble dust and

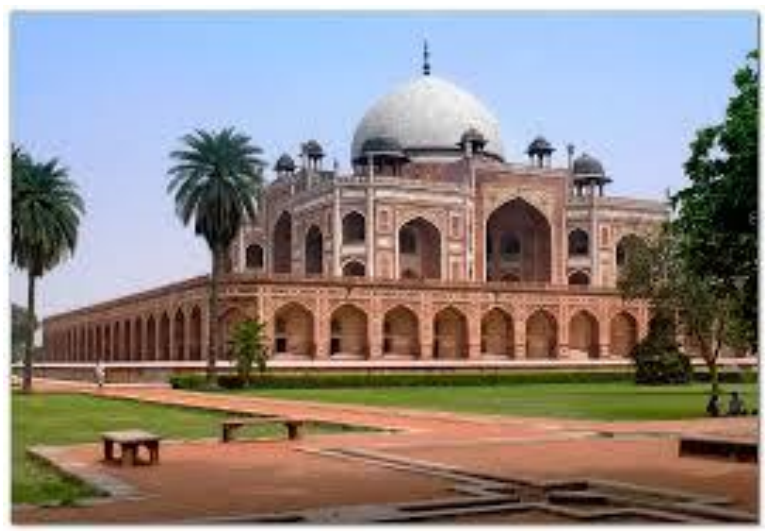

Fig.9. Humayun's Tomb Delhi.

\section{CONCLUSIONS}

lime mortars were widely used in many ancient buildings because of their good performance with reference to caking property, water repellency, weatherability, etc. The application of traditional construction materials, such as organic-inorganic lime mortars achieved an increased attention in the conservation and

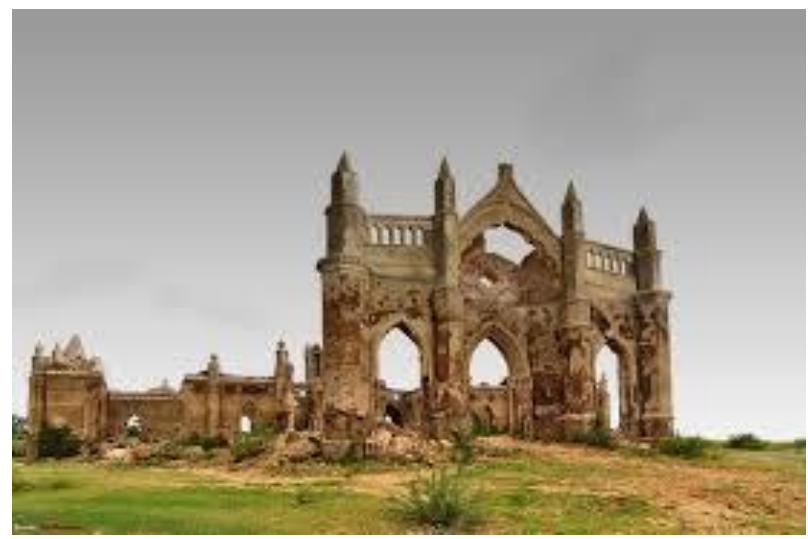

Fig 10. Rosary Church Shettyhalli Hassan

restoration of ancient buildings in the recent years. Therefore the understanding of the components of original lime mortar which remained in ancient sites is of fundamental significance particularly in terms of role of additives. Historical example demonstrated effective use of additives which are taken from nature and are sustainable. The performance of these additives is needed to be studied as they aimed to match not only to ensure 
continuity with the past, but also to ensure their visual and physical compatibility with the old.

\section{REFERENCE}

[1]. Ashurst, J., 'Mortars for stone buildings' in Conservation of Building and Decorative Stone, Vol. 2, ed. J. ASHURST and F.G. DIMES, Butterworth-Heinemann, London (1990) 78-93.

[2]. Arnold, A., And Zehnder, K., 'Evaporite und Verwitterung an Bauwerken', Eclogae geol. Helv. 77 (1984) 287-300.

[3]. Boynton, R.S., 'Lime and limestone' in Encyclopaedia of Chemical Technology, 3rd edn, Wiley, New York (1984) 343-382.

[4]. Kuhn, H., Erhaltung und Pflege von Kunstwerken und Antiquitdten, Vol. 2, Keysersche Verlagsbuchhandlung, Miinchen (1981).

[5]. Ramachandran, V.S., Sereda, P.J., And Feldman, 'Delayed hydration in white-coat plaster', Materials Research and Standards (ASTM) 4 (1964) 663-666.

[6]. Shi Qiang Fang', Hui Zhang ${ }^{\text {b, }}$, Bing Jian Zhang"a, b, , Ye Zheng a, "The identification of organic additives in traditional lime mortar, Journal of Cultural Heritage Volume 15, Issue 2, March-April 2014, Pages 144-150

[7]. Thomson, M.L., 'Plasticity, water retention, soundness and sand carrying capacity: what a mortar needs' in Proceedings of the International RILEM Workshop on Historic Mortars: Characterisation and Tests, ed. P. BARTOS, C. GROOT and J.J. HUGHES, RILEM Publication S.A.R.L. (2000) 163172.

[8]. Webb, T.L., 'Chemical aspects of unsoundness and plasticity in building limes', The South African Industrial Chemist 6 (1952) 290-294.

[9]. file:///C:/Users/User/Downloads/0045_lime $\% 20$ mortars.pdf

[10]. file:///C:/Users/User/Downloads/Pointingwith-Lime-Mortars-ENG_439kb.pdf

[11]. http://www.buildingconservation.com/article s/pozzo/pozzo.htm

[12]. file:///C:/Users/User/Downloads/2015_04__aktc_-

_batashewal_mughal_garden_tomb_comple x_brief.pdf

[13]. https://www.goodreads.com/author_blog_po sts/5554410-the-thieves-tower-delhi-s-chorminar

[14]. http://www.inthrissur.in/thrissurdirectory/ind ex/vadakkunnathantemple

[15]. http://www.hindustantimes.com/art-andculture/monumental-task-saving-india-s- rich-heritage/storyElv4ZQAPgWwArdi4i6akfJ.html

[16]. http://www.thenewsminute.com/article/batte red-edifice-hemavathy-hassan-ruins-holyrosary-church-45065

[17]. http://www.summitpost.org/hiran-minarsheikhupura-pakistan/848299

[18]. https://artageweb.wordpress.com/2016/09/04 /blog-post-title-2/ 